\title{
Measures to strengthen drug safety in acute care
}

\author{
Manela Glarcher, Monika Hoffberger, Tamara Fercher \\ From Safety in hospitals: from strategy to implementation Annual Scientific Meeting 2015 \\ Graz, Austria. 29-30 September 2015
}

\section{Background}

In 2010, an internal risk management report proved the occurrence of medication errors to be one out of the top five risks in Austrian healthcare companies. Medication errors were defined as any error occurring during the prescription, transcription, dispensing, and administration of medication and were registered regardless of the detection of consequences to the concerned patients' health [1]. Based on a survey, the Patient Safety Foundation of Switzerland ranked the 10 most common medication errors in acute care. The result included errors during the preparation of drugs, administration of drugs to the wrong patient, wrong dosages, inaccurate or missing documentations as well as the poor legibility of handwritten prescriptions [2]. The purpose of this study is to evaluate the medication processes in 21 acute care hospitals in Austria and to develop measures to strengthen drug safety.

\section{Material and methods}

A systematic literature review was performed. Subsequently, structured interviews of nurses and evaluation of handwritten drug prescription charts followed by an examination of oral medication via the used drug distribution systems were performed.

\section{Results}

The sample consisted of 21 hospitals. The sample consisted of 21 hospitals which prescribed 10,644 oral medications in eight months within the observed sample (Table 1).

Overall, the evaluation of charts indicated, that only $28 \%$ of drug prescriptions included all necessary information (e.g. correct drug name, dosages, route and period of administration, initialing of drug prescriptions and changes). A need for improvement was located regarding

\footnotetext{
* Correspondence: manela.glarcher@kages.at Department for Care-Quality-Controlling, Steiermärkische
} Krankenanstaltenges.m.b.H., Graz, Styria, Austria information about the route of administration and the initialing of drug prescriptions. The average incidence of all registered medication errors within the drug distribution systems of all 21 hospitals was 5.1\% [max. 17\%; min 1\%] (Figure 1). Regarding wrong dosage of drugs, an average of $0.7 \%$ [max. $5 \%$; min. $0 \%$ ] was registered and can be rated as very low. These findings correspond to the information on medication errors in drug distribution systems in Germany [3].

Structured interviews of nurses included questions about the availability of an internal control system and possibilities to avoid disturbances and interruptions while doing high risk care activities. In the meantime,

Table 1. Summary of study characteristics

\begin{tabular}{ll}
\hline Evaluation time & September 2011-April $\mathbf{2 0 1 2}$ \\
\hline Hospitals & 21 \\
\hline Wards & 109 \\
\hline Patients & 1,703 \\
\hline Oral medication & 10,644 \\
\hline Drug prescription & 7,483 \\
\hline
\end{tabular}

\section{Incidence of medication errors in drug distribution systems}

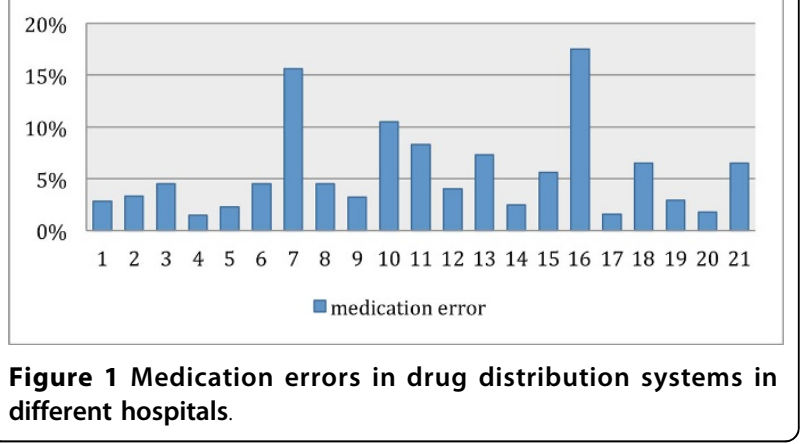


an internal control system to reduce medication errors was implemented at a total of $47.7 \%$ of all wards. Furthermore, around $45 \%$ of medical and surgical wards complained that disturbances and interruptions during the preparation of drugs couldn't be entirely avoided.

\section{Conclusions}

In order to strengthen drug safety a sustainable, interdisciplinary, modular medication training program and internal corporate guidelines for the medical staff were developed and implemented into acute care.

Published: 30 October 2015

\section{References}

1. Bohomol E, Ramos LH: Perceptions about medication errors: analysis of answers by the nursing team. Rev Latino Am Enfermagem 2006, 14(6):887-892.

2. Frank $\mathrm{O}$, Hochreutener MA: Problemfelder (Hot-Spots) in der Patientensicherheit. Ergebnisse einer Befragung in Schweizer Spitälern. Schweizerische Ärztezeitung 2008, 89:24-27.

3. Taxis K, Dean B, Barber N: Hospital drug distribution systems in the UK and Germany-a study of medication errors. Pharm Worl Sci 1999, 21(1):25-31.

doi:10.1186/2056-5917-1-S1-A29

Cite this article as: Glarcher et al:: Measures to strengthen drug safety in acute care. Safety in Health 2015 1(Suppl 1):A29.

\section{Submit your next manuscript to BioMed Central} and take full advantage of:

- Convenient online submission

- Thorough peer review

- No space constraints or color figure charges

- Immediate publication on acceptance

- Inclusion in PubMed, CAS, Scopus and Google Scholar

- Research which is freely available for redistribution

Submit your manuscript at www.biomedcentral.com/submit
C Biomed Central 